\title{
Enhancing Creativity and Change of Nursing Management Staff and Its Influencing on Their Performance at Benha University Hospital
}

\author{
Shaimaa Mohamed Araby Ebraheem¹, Gehan Mohamed Ahmed², Howida \\ Hassan El-sayd Mahfouz ${ }^{3}$ \\ ${ }^{1}$ Assistant lecturer, Nursing Administration, Faculty of Nursing, Benha University, ${ }^{2}$ Professor, \\ Nursing Administration, Faculty of Nursing, Helwan Univeristy, ${ }^{3}$ lecturer, Nursing \\ Administration, Faculty of Nursing, Benha University.
}

\begin{abstract}
Currently, organizations work in very competitive and uncertain dynamic environment, which requires organizations to be flexible, to acquire and adapt new knowledge, new technologies and new processes to introduce new products, services, cut costs, act faster than competitors and remain competitive. Purpose of the study: Enhance creativity and change of nursing management staff and it's influencing on their performance at Benha University Hospital. Design: A quasi-experimental design was utilized. The subjects were 98 head nurses, their assistants. Instruments for data collection: four instruments were used: (1) Knowledge Questionnaire Sheet, (2) Nursing Management Staff Observation Checklist (3) Nursing Management Staff Attitude toward Creativity and Change at work Questionnaire. (4) Creativity Questionnaire. The result showed that, There was improvement in the level of knowledge, performance, attitude toward creativity, change and level of creativity throughout post and follow up from the preprogram, There was significant positive statistical correlation between total knowledge scores with total performance scores and attitude toward creativity of the studied nursing management staff at preprogram and follow up phase of the study, there was positive statistical significant correlation between attitude toward change with performance and attitude toward creativity of the studied nursing management staff at post program and follow up program. The study concluded that, Enhance creativity and change of nursing management staff and it's influencing on their performance at Benha University Hospital. The study recommended the following: Hospital administration should provide program about enhancing creativity and change for nursing management staff, Replication of the study on a larger probability sample is highly recommended to achieve generalization of results.
\end{abstract}

Key words: Creativity, Change, Nursing management staff, Performance.

\section{Introduction:}

Creativity is recognized as one of the critical competencies for 21 st century organizations to lead or adapt to change. Creativity has emerged as a new focus up on which an organization's success and survival depends on its capability to create new knowledge and innovations which organizations have been faced with the need to change their way of thinking and make their employees capable of dealing with these daily challenges (Suifan \& AlJanini, 2017).

Creativity at work refers to the development of novel products, services and generating new ideas, processes and procedures by employees or a small group of employees to be successfully implemented within the firm to develop innovation (Maric 2017). In most organizations, a suitable system is required to allow employees to express their creativity. Thus, organizational support plays a major role in enhancing the creativity of employees where they will be motivated to upgrade the organization's performance and productivity. In reality, there are organizations that give insufficient 


\section{Enhancing Creativity and Change of Nursing Management Staff and Its Influencing on Their Performance at Benha University Hospital}

support to their employees in terms of empowering employees and knowledge sharing (Ibrahim and Shahbudin, 2016). Employees' creativity can be nurtured by leadership styles as leader's primarily work to initiate employees' creative abilities so they can find creative solutions for complex problems. Leadership can be seen as a situational factor that exerts a strong influence on creativity and leadership. Furthermore, it has been closely related to employees' creativity. Managers may inspire and motivate subordinates to go beyond their abilities in providing a better way of completing their tasks and solving problems, apply unconventional solutions to problems. Managers have an even more major role in creating and forming conditions that encourage cognitive processes considered helpful for fostering creativity (Mittal and Dhar, 2015; Uusi-Kakkuri 2017).

At present, the rapid changes are happening so fast that have prompted today's organizations to ensure their survival by the launch of creative products and services with advanced technology, and this requires creativity, innovation and entrepreneurship (Fadaee and Abd Alzahrh 2014). When change is announced in an organization staff hope that the outcomes for themselves (and at times for others, too) will be favorable. Changes affect the employee's performance in various ways like redundancy, employee turnover and the level of motivation at work (Kute \& Upadhyay, 2016).

Organizational change is expressed as "an empirical observation of difference in form, quality, or state over time in an organizational entity. The entity may be an individual's job, a work group, an organizational strategy, a program, a product, or the overall organization" (Franklin and Aguenza, 2016). There are several types of change that managers can adopt to help their organizations achieve desired future status as planned, emergent, episodic (also called discontinuous change) and continuous change, changes to core and peripheral systems and strategic and operational change (Khosa et al., 2015).

Resistance to change has been recognized as one of the important factors that can influence the success of organizational changes, including new technology innovation, new policies, and new organizational structure. Change may be resisted because it threatens the way people make sense of the world, calling into question their values and rationality and prompting some form of selfjustification or defensive reasoning. Successful organizational adaptation is increasingly reliant on generating employee support and enthusiasm for proposed changes, rather than merely overcoming resistance (Repischak, and Hughes 2016 ; Yuh-Shy, 2017).

Change management is an essential means to respond to future challenges, change management refers to the process of renewing an organization's direction, structure, and capabilities to improve the quality of work provided (Saarnio et al., 2016). Change requires managers and the organization as a whole, to address beliefs and mindsets and to develop the practices and behaviors that help people adapt to change. It's about enlisting people in change and keeping them committed throughout, in the face of uncertainties, fears, and distractions (Dinwoodie et al., 2015).

Managers should identify influential individuals who may be inclined to resist the proposed digital change, and be prepared to personalize benefits communications with these stakeholders, possibly at the senior sponsorship level. Inclusive, extensive and transparent communications will help encourage adoption of the digital strategy, by giving anyone who is interested an opportunity to be part of the solution (Austring 2014 and Blake, 2016).

The performance of managers and their employees improves by establishment of 


\section{Enhancing Creativity and Change of Nursing Management Staff and Its Influencing on Their Performance at Benha University Hospital}

strong culture, support creativity and positive change of an organization, manager's performance would be considered as backbone of an organization as it leads to its development effectively and the loyalty of employee relies upon knowledge and awareness of culture that improves behavior of organization (Wanza and Nkuraru, 2016).

\section{Significant of the study:}

After the exposure of the country's revolutions, especially the revolutions in Egypt and notable development and change for the better, It happened in many areas, especially in health care in all over the world, all of these stimulate and need innovation, creativity and positive change toward the best, so that it's paramount important to nursing managers tend to be creative and able to lead change positively in the way to perform duties assigned to keep up with development. Additionally when the researcher contact with nursing management staff in Benha university hospital during practical training of students found that they don't use creativity and change to solve some existing problems at work and when they perform some procedures more efficient to decrease time to be wasted or change to reduce unnecessary workload. So this study will be done to enhance nursing managers toward creativity \& change and its influencing on their performance at Benha University Hospital.

\section{Purpose of the study:}

The purpose of the study is to evaluate enhancing creativity and change of nursing management staff and its influence on their performance at Benha University Hospital through:

1. Assessing nursing management staff knowledge toward creativity and change in their work thorough program.

2. Assessing nursing management staff actual performance toward creativity and change at their work thorough program.
3. Assessing nursing management staff attitude toward creativity and change at work thorough program.

4. Assessing nursing management staff about their level of creativity at work thorough program.

5. Designing educational program for enhancing creativity and change of nursing management staff at work.

6. Implementing educational program for enhancing creativity and change of nursing management staff at work.

\section{Research Hypotheses}

Nursing management staff who receive educational program about creativity and change in their work will be improving in nursing management staff knowledge, skills and attitude toward creativity and change at work after implementing the program and it will be having a positive influence on their performance At Benha University Hospital.

\section{Methods:}

Design: A quasi-experimental research design with pre-test, post-test and follow up after three months assessments was carried out in the study.

Setting: The current study was conducted in all units at Benha University Hospital, the total number of the studied units were (57) units.

Sumpling: The sample included in the present study consisted of:

All the available nursing management staff (103) consist of : they were "Hospital director (1), assistants director (4), supervisors (10), head nurses and their assistants (88) who were working in the above mentioned study setting having at least one year of their job experience, all of them participate in the study except (3) head nurses in holidays as (sick leave child care) at the time of data collection and (2) head nurses refuse to participate in the study, the actual number of nursing management staff included in this study was (98). 


\section{Enhancing Creativity and Change of Nursing Management Staff and Its Influencing on Their Performance at Benha University Hospital}

Instruments of data collection: Data for the present study was collected through using the following four instruments:

Instruments one: Knowledge structured interveiw Questionnaire:

A structured questionnaire developed by the researcher through review of the current related literature (Ariffin, \& Daud, 2011, Wageeh, \& Nafei1, 2014 , Henry, \& Hornstein, 2015; Rashed, et al., 2015 and Indradevi, \& Rebeka, 2015). It included two parts;

- First part: Nursing management staff social charactaristics like (age, education, years of experience, training about creativity and change).

- Second part: knowledge about creativity and change at work, It included nursing management staff knowledge about creativity and change at work through program phases, It consisted of 50 items about creativity and change at work. Assessment of reliability was measured by using Cronbach's Alpha and the value was (0.894).

\section{Scoring system:}

The questions were scored as "1" for correct, and "Zero" for incorrect so the total scores were (50), and cut point was done at $60 \%=30$ scores. Total knowledge score was calculated as follows;

- Unsatisfactory: < $60 \%$ score $(0-<30)$.

- Satisfactory: $\geq 75 \% \quad$ score $(\geq 30)$.

Instruments two: Nursing Management Staff Observation Checklist:

It was an observation checklist adopted by (El-Shahat, 2014; Fathy, 2015) and adapted by the researcher. This tool aims at assessing performance of nursing management staff through program, related to creativity and change at work. Assessment of reliability was measured by using Cronbach's Alpha and the value was (0.835). It consists of 52 items about:
- Staff management (34 items) distributed as staff education (8 items), staff promotion (15 items), staff supervision (6 items), and staff evaluation (5 items).

- Patient care management (11 items).

- Unit management (7 items).

\section{Scoring system:}

The scoring system of the observational checklist was based on a three-point Likert scale as follows: completely done (2 points), incompletely done (1 point) and not done (zero point).The total scores (104) and cut point was done at $60 \%=63$ scores. The range scores of observational checklist were expressed as follows;

- Poor $=<60 \% \quad$ score $(0$ $<63)$

- Average $=60 \%-<75 \%$ score $(63-<$ 78)

- Good $=\geq 75 \% \quad$ score $(\geq 79$ 104)

Instruments three: structured questionnaire about nursing management staff attitude toward creativity and change:

The structured questionnaire modified by the researcher through reviewing the related literature as (Saleh, et al., 2013; Nafei, 2014). It included different items to assess nursing management staff attitude toward creativity and change at work. It consists of (78) items about:

Attitude toward creativity (24 items) distributed as the pattern of creativity at work (5) items, encouragement of creativity by superiors and hospital management (14 items), the constraints that limit creativity at work (15).

Attitude toward change (54 items) they are distributed as development of person s' skills (12 items), participation in the change (14 items), the confidence of people to the change (8 items), fear from the consequences of change (4 items), support change by the hospital administration (11 items), attitude of 


\section{Enhancing Creativity and Change of Nursing Management Staff and Its Influencing on Their Performance at Benha University Hospital}

nursing staff from the change at work (5 items).

\section{Scoring system:}

Scores of answers for each question were as follows: (2) always, (1) sometimes, (0) never. The participant who had a percent more than $75 \%$ this indicates a highly positive attitude, if the score ranges from 50 to less than $74 \%$, this indicates a positive attitude and if it goes less than $60 \%$, this refers to negative attitude. Total attitude score was calculated as follows;

\section{I- Attitude toward creativity:}

- Negative: $<60 \%$ score $(0-$ $<29$ )

- Positive: $60 \%$ - $<75 \%$ score $(29$ $-<36)$

- Highly Positive : $\geq 75 \% \quad$ score $(\geq 37-48)$.

- Reliability of Attitude toward creativity was measured by using Cronbach's Alpha and the value was (0.764).

\section{II- Attitude toward change:}

- Negative: $<60 \%$ score $(0-<65)$

- Positive: $60 \%$ - $<75 \%$ score $(65-<81)$

- Highly Positive: $\geq 75 \% \quad$ score ( $\geq 82-108)$.

- Reliability of attitude toward change was measured by using Cronbach's Alpha and the value was (0.875).

\section{Instruments} four: Creativity Questionnaire Sheet:

It was structured questionnaire and modified by the researcher through reviewing the related literature as (Tawfiq, 2009; Gumusluoglu, \& Ilsev, 2009 ; Saleh, et al., 2013). It included different items to assess nursing management staff level of creativity at work, Assessment of reliability was measured by using
Cronbach's Alpha and the value was (0.842).

It consisted of 59 items as follow:

- General features that characterize personality (20) items.

- Degree of flexibility in the work (8 items).

- Sensitivity to solve problems (14 items).

- Keep the direction or goal (11 items).

- Accept the risk at work (6 items).

\section{Scoring system:}

Within the creativity questionnaire sheet, there is a three-point Likert scale as follows : disagree (1 point), Agree (2 point) and strongly agree (3 point) and total scores (59). Total score was developed by Saleh, et al., (2013) and modified by the researcher as follow;

- Below creative: $<60 \%$ score $(1-\leq$ 106).

- Average creative: $60 \%$ - $<75 \%$ score (107- $\leq 133)$.

- Very creative: $\geq 75 \% \quad$ score $(\geq 133)$.

Pilot study: A pilot study was conducted on $10 \%$ form the subject : (10) head nurses, their assistants, it was done to assess the feasibility, clarity and time required to fill the tools that approximately ranged from $35-50$ minutes.

\section{Procedure:}

- The preparation, construction and approval of the data collection tools consumed around three months from March (2016) to May (2016). Then, the researcher started to assess the readiness of the subjects in the study setting to announce and encourage subjects' participation in the study.

- At Benha University Hospital: The head nurses, their assistants and each individual nursing unit were then contacted, and agreed to attend the educational program. They also, agreed 
to provide the learning room in their units for this purpose.

- During the period from October till November 2016, the researcher conducted the pilot study on $10 \%$ of the total sample (10 head nurses, their assistants, were included in the main study subject.

- The researcher started the preparation of an educational program of the creativity and change at work after reviewing the related literature.

- Sufficient questionnaires and program situations for the number of qualified staff within each unit were distributed.

- Detected needs were transformed to development in-service education program. An in-service education program was developed based on determined needs and relevant review of the literature, then translated in to English language.

- Program targets were all head nurses and their assistants working in Benha University Hospital at least one year of job experience. It was aiming to prepare and develop an educational program of the creativity and change at work. Different instructional strategies, method of teaching, media and method of evaluation were selected to suit the learner's needs, and achieve the objectives and contents of the program. The teaching sessions were (14) hours distributed as the follows: (7) sessions, (2) hours for session, achieved by using available resources, relevant contents, and instructional strategies for each session. Different methods of teaching were used such as lecture, group discussion, and brain storming. Instructional media included, handout prepared by the researcher and distributed to participants in the first day of the training.

- Conduction of the educational program of the creativity and change lasted along 3 months from June till July, 2016.
- The subjects were divided in to (6) groups according to their departments, the first (2) group were 16 and the second (2) groups were 15 and finally (2) group were 18 head nurse and their assistants . The program took about (10) days. The duration of each session was two hours depending on workload and including periods of discussion according to their achievement, progress and feedback. It started at (11.30) A.m to (1.30) P.m. At the beginning of each sessions an orientation to the training and its aims took place. Feedback was given at the beginning of each session about the previous one and at the end of each session about the current session and program situations given to participants to write their suggestion for alternative solutions.

- During the period from December (2016) to January (2017), the impact of the in-service education program was evaluated, using the same tools and situations which were used before the program. And the data was analysis and the results interpreted, and clinical significance of finding evaluated for comprehended discussion of the data analysis results of the study.

\section{Ethical consideration:}

The study will be conducted with careful attention to ethical standards of research $\&$ rights of the participants:

\section{1- Informed consent}

Informed consent will be obtained by explaining purpose, nature time of conducting the study, potential benefits of the study, methods of data collection, expected outcomes and the respondent rights to withdraw from the research study at any time in case of violation of his rights.

\section{2- Anonymity \& confidentiality}

The respondent will be assured that the data will be treated as strictly confidential; furthermore, the respondent anonymity 


\section{Enhancing Creativity and Change of Nursing Management Staff and Its Influencing on Their Performance at Benha University Hospital}

was maintained as they didn't want to write their names on questionnaires.

\section{Statistical design}

Data were verified prior to entry into the computer. The Statistical Package for Social Sciences (SPSS version 15.0) was used for that purpose, followed by data analysis and tabulation. Descriptive statistics were applied quantitative data (e.g., $\mathrm{P}$ value, Chi square, frequency, percentages, $\mid \mathrm{T}$ test). Statistical significance difference was considered if $\mathrm{p} \leq 0.05$ and a highly significant level value was considered when $\mathrm{p} \leq 0.001$.

\section{Results}

Table (1). Illustrated that distribution of nurses according to their personal characteristics; Regarding to age the mean age of the studied nursing management staff was (41.32 \pm 8.38$)$ years old, about more than two fifth $(42.9 \%)$ were aged $45-<55$ years old and $(4.1 \%)$ were aged $55-<57$ years. as regarding to sex, the majority $(92.9 \%)$ of them were female, less than three quarters of them (72.4) were married and the minority $(5.1 \%)$ of them were single. As for their educational qualification more than two thirds of them $(62.2 \%)$ had Bachelor of Nursing.

Figure (1). shows that, there was a highly significant improvement in level of knowledge of the studied nursing management staff about change and creativity throughout post and follow- up phases after three months of program more than preprogram phase; majority of them $(94.9 \%)$ had satisfactory knowledge level post program, and minority (5.1\%) had un satisfactory knowledge level.

Figure (2). Illustrate that, there was a highly significant improvement in the level of performance of the studied nursing management staff about change and creativity throughout post and follow up phases after three months of program from the preprogram phase, performance of them was good among more than two thirds of them $(69.4 \%)$ at post program and none of them $(0.0 \%)$ had poor performance at post program and follow up .

Figure (3). clarifies that, there was a highly significant improvement in attitude of the studied nursing management staff toward creativity throughout post and follow up more than preprogram phase . majority of them $(88.8 \%)$ had highly positive attitude at post program and none of them $(0.0 \%)$ had negative attitude at post program and follow up phase of the study.

Figure (4). represents that, there was a highly significant improvement in attitude of the studied nursing management staff toward change throughout post and follow up more than preprogram phase . Attitude was highly positive among majority of them $(94.9 \%)$ at post program and none of them $(0.0 \%)$ had negative

attitude at post program and highly positive at pre- program phase of the study.

Figure (5). It is clear from this figure that, there was an improvement in a level of creativity of studied nursing management staff throughout post and follow up more than preprogram phase. majority of them were $(94.9 \%)$ very creative level of creativity at post program and none of them $(0.0 \%)$ had below level at post program and follow up and very creative level at pre program phase of the study.

Table (2): revealed that, there was positive statistical significant correlation at total knowledge scores with total performance scores and attitude toward creativity of the studied nursing management staff at preprogram and follow up phase of program. Also, it was clear from this table that there was positive statistical significant correlation between attitude toward change with performance and attitude toward creativity of the studied nursing management staff at post and follow up phase of program. 
Enhancing Creativity and Change of Nursing Management Staff and Its Influencing on Their Performance at Benha University Hospital

Table (1) Distribution of personnel characteristics of the studied nursing management staff $(n=98)$.

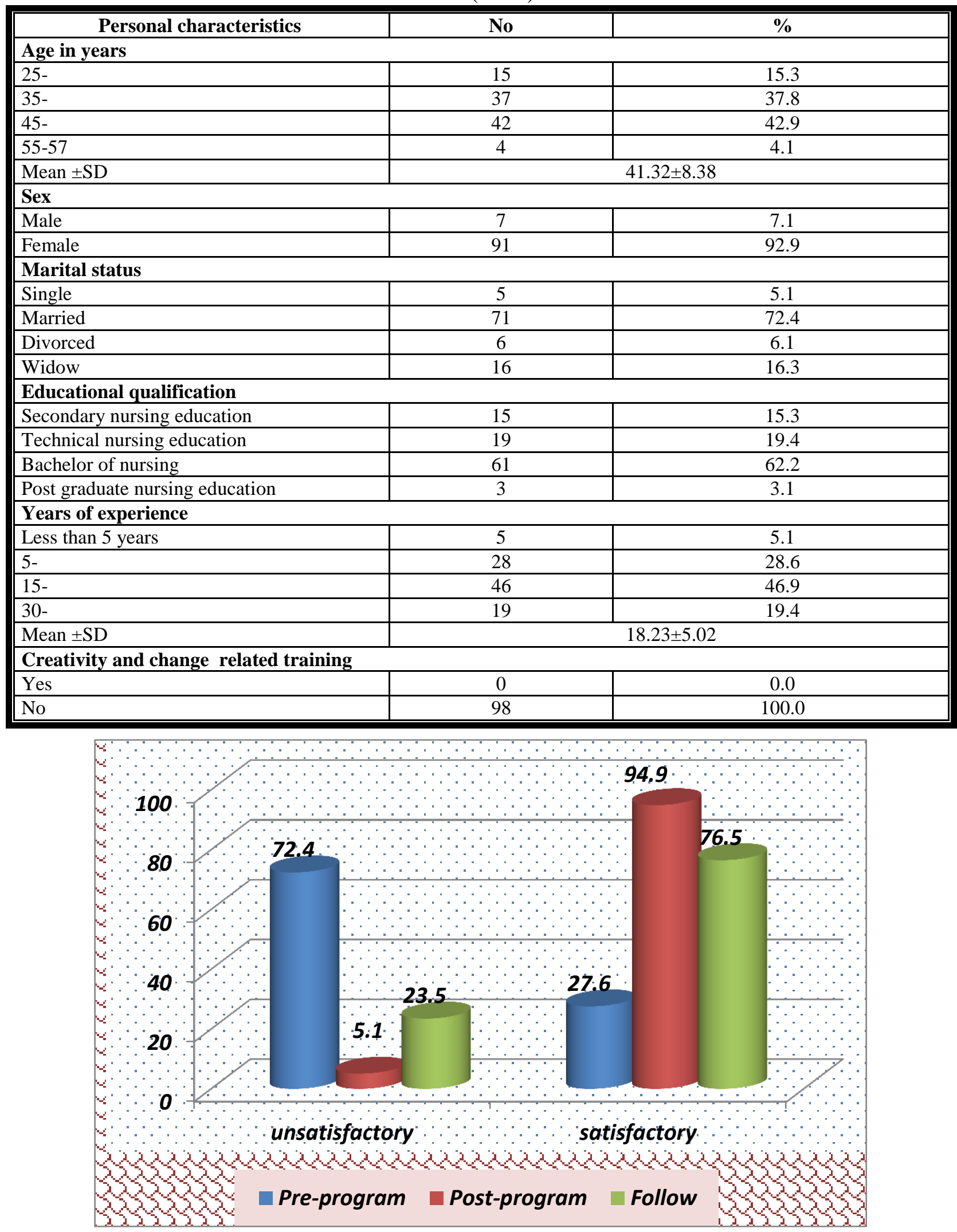

Figure (1). Distribution of nursing management staff according to their level of knowledge regarding creativity and change at work. Pre, immediate, and three months post and follow up program implementation. $(n=98)$. 
Enhancing Creativity and Change of Nursing Management Staff and Its Influencing on Their Performance at Benha University Hospital

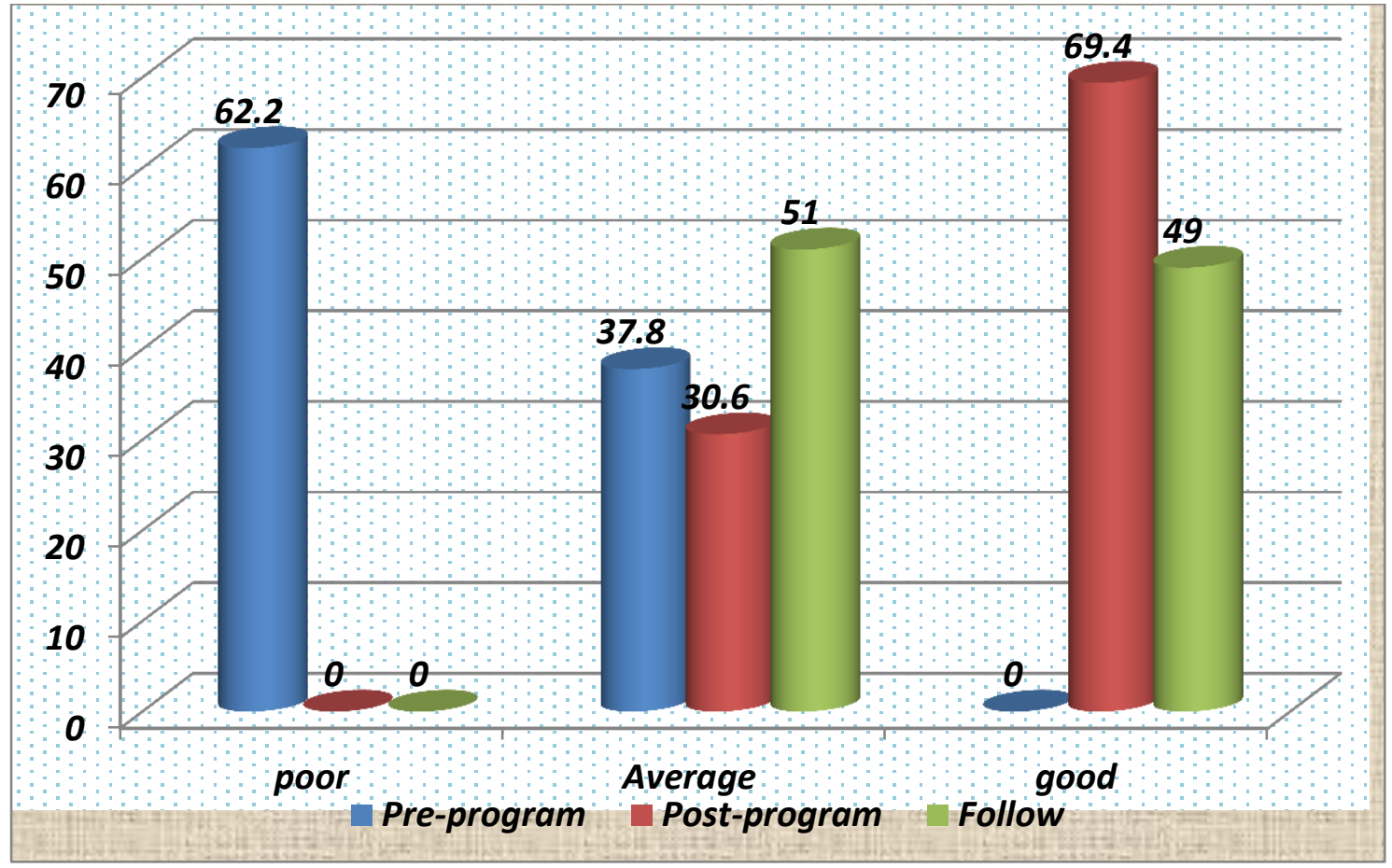

Figure (2). Level of performance of the studied nursing management about creativity and change at work. Through the program phases. $(n=98)$.

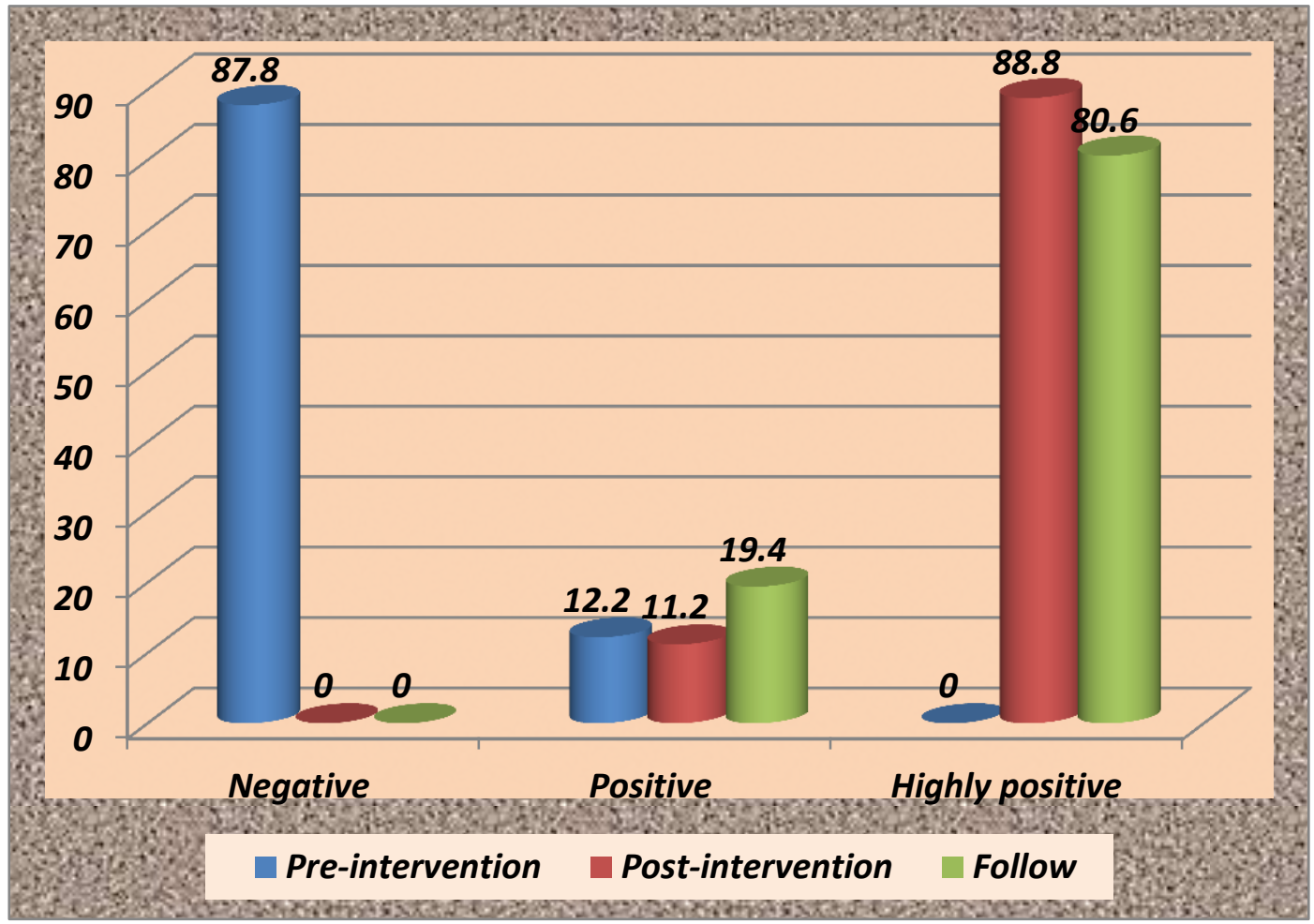

Figure (3). Level of nursing management staff attitude toward creativity. Pre, immediate, and three months post program implementation. $(n=98)$. 
Enhancing Creativity and Change of Nursing Management Staff and Its Influencing on Their Performance at Benha University Hospital

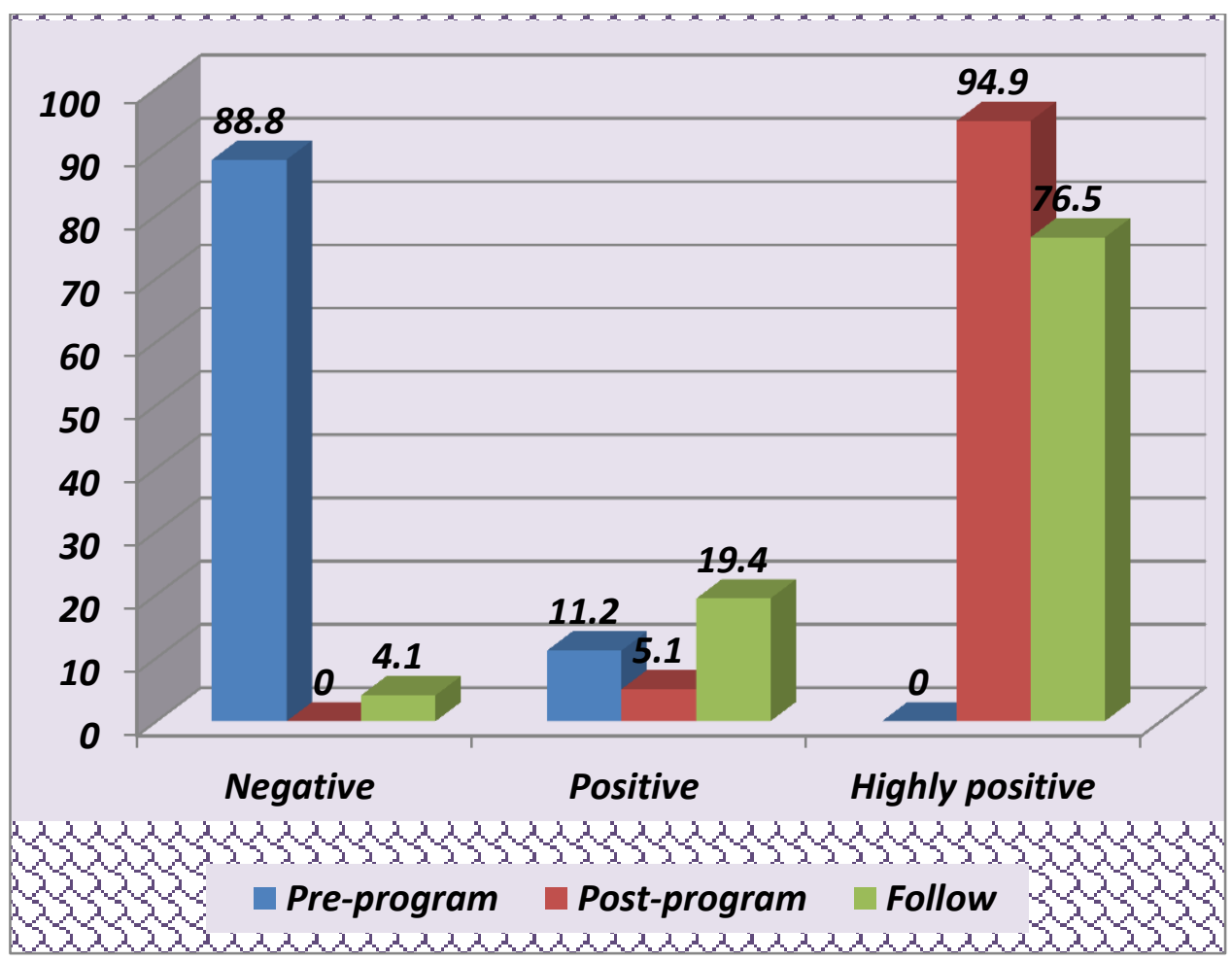

Figure (4). Attitude toward change scores of the studied nursing management staff . Pre, immediately post, and three months post program implementation. ( $n=98)$.

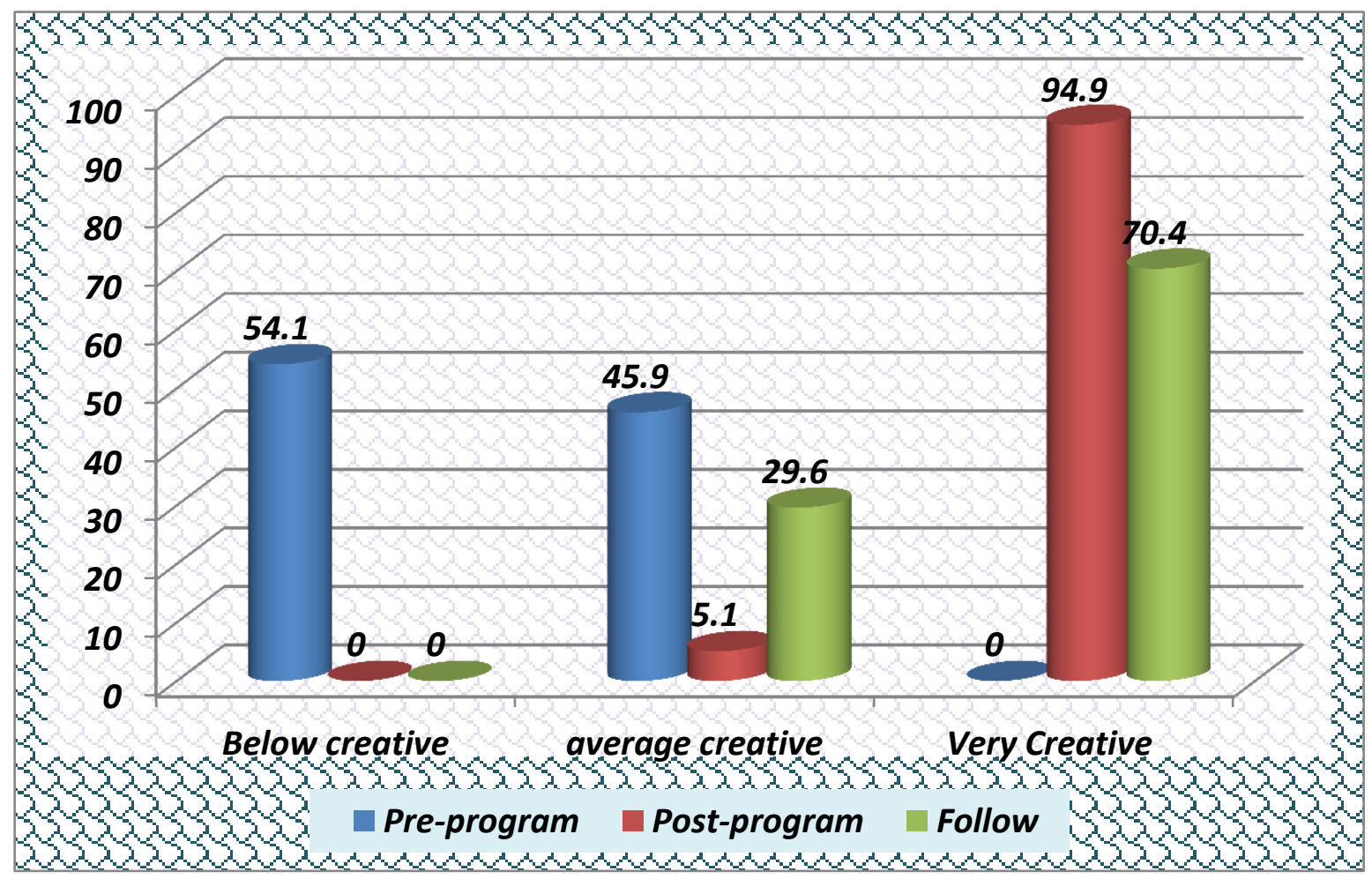

Figure (5). Level of creativity at work of studied nursing management staff . Pre, immediately post, and follow up program implementation. $(\mathrm{n}=98)$. 
Table (2) Correlations between studied variables of creativity and change of studied nursing management staff pre, immediately post, and follow up program implementation. $(n=98)$.

\begin{tabular}{|c|c|c|c|c|c|c|c|c|c|c|c|}
\hline \multirow{2}{*}{ Variable } & \multirow{2}{*}{ 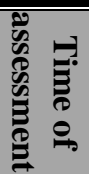 } & \multicolumn{2}{|c|}{$\begin{array}{c}\text { Attitude toward } \\
\text { change }\end{array}$} & \multicolumn{2}{|c|}{ Creativity level } & \multicolumn{2}{|c|}{ Performance } & \multicolumn{2}{|c|}{$\begin{array}{c}\text { Attitude toward } \\
\text { creativity }\end{array}$} & \multicolumn{2}{|c|}{ Knowledge } \\
\hline & & $\mathbf{r}$ & $\begin{array}{c}P \\
\text { value }\end{array}$ & $\mathbf{r}$ & $P$ value & $\mathbf{r}$ & $\begin{array}{c}P \\
\text { value }\end{array}$ & $\mathbf{r}$ & $\begin{array}{c}P \\
\text { value }\end{array}$ & $\mathbf{r}$ & $\begin{array}{c}\mathbf{P} \\
\text { value }\end{array}$ \\
\hline $\begin{array}{l}\text { Attitude toward } \\
\text { change }\end{array}$ & \multirow{5}{*}{ 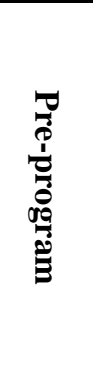 } & 1 & --- & .023 & .822 & .036 & .723 & .118 & .247 & -.070 & .491 \\
\hline Creativity level & & .023 & .822 & 1 & $-\cdots$ & .115 & .258 & .078 & .448 & .020 & .849 \\
\hline Performance & & .036 & .723 & .115 & .258 & 1 & $-\cdots$ & .026 & .798 & $.353^{* *}$ & .000 \\
\hline $\begin{array}{c}\text { Attitude toward } \\
\text { creativity }\end{array}$ & & .118 & .247 & .078 & .448 & .026 & .798 & 1 & --- & $.370^{* *}$ & .000 \\
\hline $\begin{array}{c}\text { Knowledge } \\
\text { toward change } \\
\text { and creativity }\end{array}$ & & .070 & .491 & .020 & .849 & $.353^{* *}$ & .000 & $.370^{* *}$ & .000 & 1 & --- \\
\hline $\begin{array}{l}\text { Attitude toward } \\
\text { change }\end{array}$ & \multirow{5}{*}{ 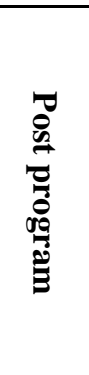 } & 1 & -- & $.211^{*}$ & .037 & $.548^{* * *}$ & .000 & $.335^{* *}$ & .001 & .062 & .542 \\
\hline Creativity level & & $.211^{*}$ & .037 & 1 & -.-- & $.220^{*}$ & .030 & .120 & .240 & .038 & .707 \\
\hline Performance & & $.548^{* *}$ & .000 & .220 & $.030^{*}$ & 1 & $-\cdots$ & $.265^{* * *}$ & .008 & .082 & .423 \\
\hline $\begin{array}{c}\text { Attitude toward } \\
\text { creativity }\end{array}$ & & $.335^{* *}$ & .001 & .120 & .240 & $.265^{* *}$ & .008 & 1 & --- & .016 & .875 \\
\hline $\begin{array}{c}\text { Knowledge } \\
\text { toward change } \\
\text { and creativity }\end{array}$ & & .062 & .542 & .038 & .707 & .082 & .423 & .016 & .875 & 1 & --- \\
\hline $\begin{array}{l}\text { Attitude toward } \\
\text { change }\end{array}$ & \multirow{5}{*}{ 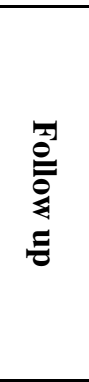 } & 1 & $\cdots$ & -.102 & .320 & $-.307^{* *}$ & .002 & .109 & .286 & .166 & .103 \\
\hline Creativity level & & .102 & .320 & 1 & $\cdots$ & $.254^{*}$ & .012 & .082 & .424 & .103 & .314 \\
\hline Performance & & $.307^{* *}$ & .002 & $.254^{*}$ & .012 & 1 & $-\cdots$ & .177 & .081 & $.419^{* * *}$ & .000 \\
\hline $\begin{array}{l}\text { Attitude toward } \\
\text { creativity }\end{array}$ & & .109 & .286 & .082 & .424 & .177 & .081 & 1 & ---- & $.607^{* *}$ & .000 \\
\hline $\begin{array}{c}\text { Knowledge } \\
\text { toward change } \\
\text { and creativity }\end{array}$ & & .166 & .103 & .103 & .314 & $.419^{* *}$ & .000 & $.607^{\text {** }}$ & .000 & 1 & --- \\
\hline
\end{tabular}

** Correlation is significant at the 0.01 level (2-tailed).

*Correlation is significant at the 0.05 level (2-tailed).

\section{Discussion}

The purpose of study to assess enhances creativity and change of nursing management staff and it's influencing on their performance at Benha University Hospital. The results of the present study covered the main areas following:

\section{I: Personal characteristics of nursing management staff:-}

From personal characteristics of nursing management staff included in the study setting; Regarding to age about more than two fifth were aged $45-<55$ years old and minority were aged $55-<57$ years. These findings were in similarity with Saleh, et al., (2013), who revealed in their study on nurses leaders in Assiut University Hospital that more than half were aged $>30$ years. This result in disagreement with Aly, et al., (2016), who revealed in his study on head nurses in Critical Care Units in Alexandria University Hospitals that minority were aged 55- $<57$ years.

As regarding to sex, the majority of them were female, less than three quarters of them were married and the minority of them were single. These finding followed the same line of Wang, et al., (2016), who revealed in their study of head nurses in nursing units of two hospitals in Taiwan that majority of them were female. This result in 
disagreement with Al Shehri, et al., (2013) who found in their study of health managers in health sector of Saudi Arabia that more than fifth of them were male.

As for the educational qualification, more than two thirds of studied sample have bachelor of nursing. And the minority of them was post graduate nursing education. These findings were in similarity with $\mathrm{Al}$ sayaydeh, (2015) who revealed in their study of leaders of the Intermediate Colleges of Balqa Applied University, European that more than two thirds of them had bachelor of nursing. This result inconsistent with ALJazaery, and Khaleel, (2016), who revealed in their study on head nurses that minority of them nursing college graduate.

With respect to years of experience more than two fifth of them had $15-<30$ years, and minority of them had less than 5 years of experience, These finding were in similarity with Saleh, et al., (2013), who revealed in their study that more than third of them had 15-< 30 years. This result in disagreement with Al sayaydeh , (2015), who found in their study of leaders more than third of them have less than 5 years of experience.

\section{II: Nursing management staff knowledge about creativity and change in their work:-}

The present study shows that, a highly significant improvement in level of knowledge of the studied nursing management staff about change and creativity throughout post and follow up more than preprogram phase. These findings were similar to some Egyptian studies such as Rashed, (2017), who reported in his study that a statistical significant difference was observed between their knowledge mean scores obtained in the pre- test and post-test and follow up. This result disagreed with Abd El-Aziz, (2009), who reported that there was no statistically significance difference in relation to all items of knowledge about conflict and its resolution strategies which is essential to apply creativity and change at work In addition to the head nurses with experience
20 years had better knowledge than head nurses who have less than 10 years of experience.

From the researcher point of view, this improvement in the knowledge of the nursing management staff could have attributed to utilizing creative teaching approaches that facilitated the interactions and collaboration in the learning process, However, increasing knowledge acquired by nursing management staff could be explained by the fact that learning provided a passive experience and courses created an interactive environment. In addition, the several cycles of repetition created a truly dynamic interactive educational sessions.

III: Nursing management staff actual performance toward creativity and change at their work thorough program:The current study revealed that, there was a highly statistical significant improvement in the level of performance of studied nursing management staff in relation to change and creativity throughout post and follow up more than preprogram phase, These findings were similar to El-Shahat, (2014), who found that there were a highly significant differences related to clinical supervision performance assigned by the head nurses and their assistants throughout the three phases of the program; pre, immediate post program, and follow up after three months.

From researcher point of view that it is important for nursing management staff to develop effective open communication between nurses that a major factor that influences job satisfaction. It is the most important skill in leadership, decisionmaking, problem- solving, team-work, training, members involvement and empowerment, and all other areas of concern to modern management that motivate them to be creative and apply creativity and change at work place.

IV: Nursing management staff attitude toward creativity and change at work thorough program:- 
The current study revealed that there was a highly statistical significant improvement in the attitude of the studied nursing management staff toward creativity. Majority of them had highly positive attitude at post program and follow up phase of the study. This result is in agreement with Aburuman, (2016), who elaborated in his study on workers of Jordanian Public Administration Institute that there is significance difference level in the workers' tendencies towards creativity improvement.

Moreover, this improvement in attitude toward creativity and change may be due to head nurses feeling that, administrative staff are a friend to them, they looks to satisfy nurses, and follow the work of others, also may be due to that, nursing management staff put their concentration on work and first priority for their was to achieve efficiency of work and take care of the staff.

VI: Nursing management staff level of creativity at work thorough program:-

The current study shows there was a highly statistical significant improvement in the level of creativity of studied nursing management staff throughout post and follow up phases after three months of program from the preprogram phase. This result was in agreement with Panatik, et al., (2016), who revealed in their study that the level of creativity was high among research officers in Malaysia post program application.

This result were inconsistent with Ali, and Elhakem, (2015), who elaborated in their study on managers on Sudanese institutions that the office executive managers of various departments had high level of creativity.

VII: Correlations among studied variables of creativity and change of studied nursing management staff:-

The findings of the study revealed that there was positive statistical significant correlation between total knowledge scores with total performance scores and attitude toward creativity of the studied nursing management staff at preprogram and follow up phase of the study. This finding is supported by Khosa, et al., (2015) and Rogers, (2014).

In researcher opinion, relation nursing management staff ' knowledge and performance could occur when improvement in knowledge resulted in utilizing creative and attractive teaching approaches and use of educational strategies that can facilitate the interactions, collaboration and discussion in the learning process and this might have effect on increased performance for the nursing management staff.

\section{Conclusion}

The present study concluded that the training program was effective i.e. There was an improving in the level of knowledge, the level of performance, the attitude toward creativity and change, the level of creativity of studied nursing management staff throughout post and follow up from the preprogram phase.

\section{Recommendations}

\section{For hospital Administration:}

1. Demonstrate a strong orientation toward creativity and change, which is clearly communicated and enacted, from the highest levels of management, throughout the hospital.

2. Make use of technology that influence employee's performance as information system since it simplifies the work to be done and also making work more efficient.

3. Putting an effective system of financial and incorporeal incentives for the employees.

\section{For nursing management staff:}

1. Conducting continuous training programs for nursing staff must be developed to educate staff on change management and how to apply creativity at workplace.

2. Match people's skills, interests and personality to the right job, so that each employee can make the most of his/her expertise, thereby stimulating intrinsic 


\section{Enhancing Creativity and Change of Nursing Management Staff and Its Influencing on Their Performance at Benha University Hospital}

motivation and diminish role ambiguity, consequently increasing creativity.

3. Provide managers with adequate resources to carry out the work, and at least minimally sufficient time to consider alternative approaches.

\section{For further researchers:}

1. Reapplication of the study on a larger probability sample in other settings is highly recommended to achieve generalizable results.

\section{References:}

Abd El-Aziz, T., (2009): Implementation of Conflict Resolution Strategies and Its Effect on Stress Level among Nursing Personnel at Benha University Hospital, Doctorate thesis , faculty of nursing , Benha university, $\mathrm{Pp}:$ : 90-91.

Aburuman, N.M., (2016) :The Impact of Administrative Empowerment on Creativity Improvement among the Workers of Jordanian Public Administration Institute, International Journal of Business and Social Science 7 (1), Pp: 182-190

Al sayaydeh, A., (2015): The Impact of Prevailing Leadership Styles on the Level of Administrative Creativity of the Staff of the Intermediate Colleges of Balqa Applied University, European Journal of Business and Management, 7(15), Pp:76-84.

Al Shehri, O., AlHarthi, A., \& Al-Khatib, J., (2013): Patterns of Creativity Trends among Health Managers in Health Sector of Saudi Arabia, Riyadh Region, European Scientific Journal, 9(6), Pp:111-128.

Ali, A., \& Elhakem, A., (2015): The relationship between the elements and obstacles of administrative innovation in Sudanese institutions, Journal of Economic Sciences, 16(1), Pp:176-182.

AL-Jazaery, A., \& Khaleel, M., (2016): Assessment of the Head Nurses'
Performance Regarding Staff Management at the Units of Al-Najaf AL-Ashraf City Hospitals, Kufa Journal For Nursing Sciences, 6 (3), Pp:119-124

Aly, A., Ghoneim, M., \& Hassan , S., (2016): Role of Head Nurses in Managing the Safety of High Alert Medications in Critical Care Units, Journal of Natural Sciences Research , 6(8), Pp:5-7.

Ariffin, S. R., Daud, F., Ariffin, R., Rashid, A.N., \& Badib, A., (2011): Profile of Creativity and Innovation Among Higher Learning Institution Students in Malaysia, World Applied Sciences Journal, 36 (41), Pp: 36- 41.

Austring, S., (2014): Creativity in Social Work Education, Pp 12-20, Available at http://blog.han.nl /inecs/ files/2014/ 01/ Creativity-in-SocialWork-Education .pdf, accessed in 22-10-2016 .

Blake , I., (2016): Change Management Institute Evolution and themes in change Management, Change Management Institute, Pp:1-9 Available at info@changemanagement-institute.com, accessed in 2-11-2017.

Dinwoodie, D., Pasmore, W., Quinn,L., \& Rabin, R., (2015): Navigating Change: A Leader's Role, white paper Center for Creative Leadership, Pp22-25 Available at https://media.ccl.org/.../navigatingchange-a-leaders-role-center-for-c. accessed in 5-2-2017

El-Shahat, M., (2014): The Effectiveness of Implementing Clinical Supervision Models on Head Nurses' Performance and Nurses' Job Satisfaction, unpublished Doctorate thesis , faculty of nursing , Benha university.

Fadaee, A., \& Abd Alzahrh, H., (2014): Explaining the Relationship between Creativity Innovation and Entrepreneurship, International 
Journal of Economy, Management and Social Sciences, 3 (12), Pp: 1:20

Fathy, S., (2015): Nursing Personal Knowledge \& Skills toward Emergency Functions and its Effect on Patient Satisfaction at Benha and Damanhur University Hospitals, Unpublished master thesis, faculty of nursing, Benha university.

Franklin, E., \& Aguenza, B., (2016): Obstacles, Resistance and Impact of Change in Organizations: An Examination of the Saudi Telecommunication Company, International Journal of Academic Research in Business and Social Sciences, 6(4), Pp: 23-30.

Gumusluoglu. L., \& Ilsev, A., (2009): Transformational Leadership, Creativity, and Organizational Innovation. Journal of Business Research, 62, Pp: 461-473.

Henry, A. \& Hornstein, E., (2015): The Integration of Project Management and Organizational Change Management is Now A necessity, International Journal of Project Management, 33, Pp: $291-298$.

Ibrahim, H., \& Shahbudin, A., (2016): Organizational Support and Creativity: The Role of Developmental Experiences as a Moderator, Procedia Economics and Finance, 35, Pp: 509 - 514.

Indradevi, R., \& Rebeka, E., (2015):A Study on Perception of Employees during Change in an Organization , Mediterranean Journal of Social Sciences, 6 (1), Pp:1:15.

Khosa, M., Rehman, U., Asad, A., Bilal, A., \& Hussain, N., (2015): The Impact of Organizational Change on the Employee's Performance in the Banking Sector of Pakistan. Journal of Business and Management, 17(3), Pp : 54-61.

Khosa, M., Rehman, U., Asad, A., Bilal, A., \& Hussain, N., (2015): The Impact of Organizational Change on the Employee's Performance in the
Banking Sector of Pakistan. Journal of Business and Management, 17(3), Pp : 54-61.

Kute, D., \& Upadhyay, P., (2016): The Impact of Technological Changes on the Performance of the Employees in Commercial Printing Industry , Journal for Contemporary Research in Management, 1, Pp:57-74

Maric, A., (2017): Creativity And Innovation: The Leadership Dynamics, Doktorski studij, Pp 1-4. available at https://www.fsb.u nizg.hr/brodogradnja/UZIR-Essay-

2017-Maric.pdf - accessed in 15-62016

Mittal, S., Dhar, L. (2015): Transformational Leadership And Employee Creativity: Mediating Role of Creative Self-Efficacy and Moderating Role of Knowledge Sharing. Management Decision, 53(5), Pp: 894-910.

Nafei, W., (2014): Assessing Employee Attitudes towards Organizational Commitment and Change: The Case of King Faisal Hospital in Al-Taif Governorate, Kingdom of Saudi Arabia, Journal of Management and Sustainability; 4(1), Pp:204-210

Panatik, A., Katiminb, F. \& Shaari, R. (2016): The Effect of Personal Factors on Creativity among Research Officers in Malaysia, Journal of Advanced Research in Social and Behavioral Sciences, 2(1), Pp: 33-48.

Rashed, M., (2017): Developing and implementing of managerial innovation skills program for nurses managers at assiut university hospitals. Doctoral Theses, Faculty of nursing, Assiut university.

Rashed, S., Al Torky, M., \& Morsey, S., (2015): Performance of head nurses management functions and its effect on nurses' productivity at Assiut University Hospital, Journal of Nursing and Health Science, 4( 5 ), Pp: 38-49 
Repischak, V., \& Hughes, C., (2017): Managing Organizational Change: A guide for Human Resource Professionals in the era of change, Human Resource Management, School of Public and Environmental Affairs, at Indiana University, available at https://www.docplayer.net/34058575 -Managing-orga nizat ion al- changea-guide-f...

Rogers, N., (2014): Job Resources, Employees' Creativity And Firm Performance Of Commercial Banks In Uganda, Commerce and Management, United Kingdom, International Journal of Economics, 9 (2): Pp1:20.

Saarnio1 R., Suhonen M., and Isola A., (2016): Nurse managers' visions of future challenges in health care organizations, Journal of Nursing, 3(2), Pp:1-5. http://www. Hoajonlin e. co m /journals/pdf/2056-9157-32.pdf

Saleh, N., ElSayed, M., Ghallab, S., \& Abd Alla, S., (2013): Nurse Leaders' Behaviors, and Its Effect on Nurses Creativity and Attitude Toward Change Main Assiut University Hospital, Journal of American Science, 9(12), Pp:906:912.

Suifan, T., \& Al-Janini, M., (2017): The Relationship between Transformational Leadership and Employees' Creativity in the Jordanian Banking Sector, International Review of Management and Marketing, 7(2), Pp: 284-292, available at http: www.econjournals.com.
Tawfiq, A., (2009):Administrative creativity and its relationship to job performance directors of the public sector, the Islamic University in Gaza, P:214. Available at http://s tclements.edu/grad/gradsaleh.pdf. accessed in 6-2- 2015

Uusi-Kakkuri P., (2017): Transformational leadership and leading creativity, Doctoral thesis, University of Vaasa Faculty of Business Studies Department of Management, Pp:226269

Wageeh, A., \& Nafei1, S., (2014): Assessing Employee Attitudes towards Organizational Commitment and Change: The Case of King Faisal Hospital in Al-Taif Governorate, Journal of Management and Sustainability, 4(1), Pp: 204:219.

Wang, C., Anthony,K., \& Wen Kuo, N., (2016): The Role of Head Nurse on Communication: A Social Network Approach, International Journal of Future Computer and Communication, 5(1), Pp: 43-46

Wanza, L., \& Nkuraru, K.J., (2016): Influence of Change Management on Employee Performance: A Case of University of Eldoret, Kenya International Journal of Business and Social Science, 7(4), Pp:190-199.

Yuh-Shy, C., (2017): Individual Resistance from Employees to Organizational Change, International Business Department, Ching Yun University, Available at cholar. google. Com /citations? user $=$ uP2fxnkAAAAJ \&hl=en, accessed in 6-12- 2016. 